\title{
R. V. Dingle Ostracod Collection: Natural History Museum, London
}

\author{
R. V. DINGLE ${ }^{1 *}$, C. GILES MILLER ${ }^{2} \&$ CLIVE JONES ${ }^{2,3}$ \\ ${ }^{1}$ St Marks Court, Cambridge CB3 9LE, UK. \\ ${ }^{2}$ Department of Palaeontology, The Natural History Museum, London SW7 5BD, UK. \\ ${ }^{3}$ Current address: Biostrat Support Services, 2 Amber Close, Bordon GU35 0XN, UK. \\ *Corresponding author (e-mail: rvdingle@aol.com)
}

\begin{abstract}
The collection was donated to the Natural History Museum (NHM) between 2009 and 2011 and consists of 2534 slides. It comprises mainly marine ostracods of Jurassic to Holocene age from southern Africa (and its adjacent oceans), Antarctica and New Zealand. There is also a small collection of Quaternary non-marine ostracods from southwestern Africa, two sets of DSDP/ODP ostracods from the Southern Ocean, and one set of Cape Roberts Drilling Project (CRDP) ostracods from Victoria Land, East Antarctica. The individual slides in this collection have been computer registered. Further details of these can be found by inputting seach criteria based on information given in the paper to the NHM's on-line catalogue at http:// www.nhm.ac.uk/research-curation/collections/departmental-collections/palaeontology-collections/search/index.php. J. Micropalaeontol. 31(2): 189-192, July 2012.
\end{abstract}

KEYWORDS: microfossils, Ostracoda, Natural History Museum, reference collection, southern hemisphere, type speciments, South Africa, Antarctic, New Zealand

\section{INTRODUCTION}

The bulk of the non-DSDP/ODP and -CRDP material was collected by RVD, with small quantities donated by colleagues and co-workers. Most of it has been described in a series of publications, and the slides are arranged in sets that relate to particular articles. The remainder is classified as 'undescribed', including suites from cores collected in 1992 from the oceanographic research vessels Professor Logachev and Benguela. Many of the specimens come from sediments collected from the University of Cape Town research vessel Thomas B Davie. The latter have a TBD prefix, and location sites and water depths are listed in the database/spreadsheet using a TBDXXXX notation. Samples with prefix AX were collected by Sea Fisheries Research Institute, Cape Town - their localities are also listed in the database/spreadsheet.

The collection has 2337 slides in the main set, with a further 197 in the New Zealand/Antarctica subset, giving a grand total of 2534 slides containing 94000 specimens. The New Zealand/Antarctica subset has NHM PM-OS numbers 16596-16792, while the main collection has NHM PM-OS numbers 16988-19324. There are holotypes, paratypes, figured specimens, topotypes, an idiotype, and a large selection of comparative material. Many of the last category are single-species collections arranged in stratigraphical sequence (either from outcrop, or cores: 'stratigraphical selections'), as well as specimens from various water depths.

The collection is listed on a spreadsheet that can be sent on request.

In summary, the main geographical/stratigraphical slide-sets are:

\section{SOUTH/SOUTHERN AFRICA}

Jurassic to Upper Cretaceous: south and southeast coasts (142 slides)

Middle to Upper Cretaceous: east coast (185 slides)

Cenozoic: onshore \& offshore (296 slides)

Quaternary: onshore \& offshore, including non-marine faunas (1093 slides)

\section{ANTARCTICA/NEW ZEALAND}

Upper Cretaceous (197 slides)

Cenozoic (119 slides)

SOUTHERN OCEAN

Middle to Upper Cretaceous (62 slides)

Cenozoic (348 slides)

Holocene (69 slides)

\section{SUNDRY MATERIAL}

Various ages (23 slides)

Details of the main sets, showing slides referred to NHM OSxxxxx and informal (RVDxxxx) numbers on cabinet drawers, are listed below.

\section{SOUTH AFRICA: JURASSIC TO UPPER CRETACEOUS - SOUTH AND SOUTHEAST COASTS \\ Brenton, Knysna. Upper Jurassic}

9 slides: OS17011-17017 (RVD24-30); OS18404-18405 (RVD 14171418). Publication: Dingle \& Klinger (1972). Faunal slides and topotypes. Figured and other type material is in the South African Museum, Cape Town. Samples collected by Dr H. C. Klinger in 1971. Age of outcrops still in dispute - probably late Jurassic; see Klinger et al. (1972).

Algoa Basin, Colchester area. Hauterivian-Valanginian 31 slides: OS16988-17010 (RVD1-23); OS18397-18403 (RVD14101416); OS18449 (RVD1462). Publications: Brenner \& Oertli (1976), Dingle (1969a; 1996), Valicenti \& Stephens (1984). Topotypes, faunal slides, stratigraphic selections, and figured specimens. Holotypes from Brenner \& Oertli (1976) and Dingle (1969a) are also in the Natural History Museum: OS7528-7545 and Io740-757, respectively. Bulk of material was collected by RVD in 1976; some individual specimens illustrated in Dingle (1996) were donated to RVD by Dr H. Valicenti (c. 1993) [i.e. comparative material relating to Brenner \& Oertli (1976) and Valicenti \& Stephens (1984)]. Undescribed faunas (OS18397-18403) were donated to RVD by Dr E. Beer (formerly of Geological Survey of South Africa, c. 1970) from CO 1/67 and BE boreholes.

South African offshore, Agulhas Bank. Barremian-Maastrichtian 29 slides: OS17047-17075 (RVD60-88). Publications: Dingle (1971a), Klinger et al. (1976). Holotypes, paratypes, topotypes and faunal slides. Material from four sites (TBD 510,818, 1113 and 1266) on the Agulhas Bank collected by RVD from the UCT R/V Thomas $B$ Davie during the period 1968-9. Some specimens from site TBD818 (Maastrichtian III) and illustrated in Dingle (1971a) also provided type material for Dingle (1981).

\section{SE Africa. Santonian-Maastrichtian}

73 slides. Publications: Dingle (1969b; 1971b; 1985; 1996), McMillan (2009). Holotypes, paratypes, topotypes, faunal slides, stratigraphical selections and comparative material. Umzamba material was collected in 1968 by Mr A. O. Thompson (at the request of RVD), and by RVD in June 1977. Needs Camp and Igoda material was collected by RVD in 1977, while some Igoda specimens were presented to RVD by Dr I. K. McMillan in 2009.

Transkei (Umzamba): OS17018-17046, 17181, 17183-17185, 17188, 17191, 17198, 17200, 17205, 18391-1 8396, (RVD31-59, 194, 196-198, 201, 204, 211, 213, 218, 1404-1409).

Eastern Cape (Needs Camp): OS17122, (RVD135).

Igoda estuary: OS17123, 17147, 18519-18544, (RVD136, 160, 1532-1557). 
SOUTH AFRICA - EAST COAST: MIDDLE TO UPPER CRETACEOUS Richards Bay borehole BH-9. Santonian-Campanian

57 slides: OS17076-17118, 18587-18600 (RVD89-131, 1600-1613). Publications: Dingle (1980), Klinger \& Kennedy (1977). Topotypes, stratigraphical selections, faunal slides and comparative material. All holotypes, paratypes and figured specimens are in the South African Museum, Cape Town. Core collected by Drennan Maud \& Partners in the 1970s as part of the survey for development of Richards Bay Harbour.

\section{Zululand. Aptian-Maastrichtian}

123 slides: OS17119-17121, 17124-17146, 17148-17180, 17182, 1718617187, 17189-17190, 17192-17197, 17199, 17201-17204, 17206-17225, 18548-18576 (RVD132-134, 137-159, 161-193, 195, 199-200, 202-203, 205-210, 212, 214-217, 219-238, 1561-1588). Publications: Dingle (1981; 1984; 1985; 1996), Kennedy \& Klinger (1975). Topotypes, stratigraphical selections, faunal slides and comparative material. All holotypes, paratypes and figured specimens are in the South African Museum, Cape Town. Material collected from outcrops by RVD in June 1977.

Offshore Natal, borehole J(c)-1. Cenomanian-Campanian

5 slides: OS18368-18372 (RVD1381-1385). Publications: Dingle (1981; 1985), Du Toit \& Leith (1974). Five faunal slides consisting of residues from type and figured material deposited in the South African Museum, Cape Town. Original samples collected by the Southern Oil Exploration Corporation (1971) and donated to RVD for analysis in 1973.

\section{SOUTH AFRICA: CENOZOIC ONSHORE \& OFFSHORE East Coast}

Publications: Dingle (1976), Du Toit \& Leith (1974), Siesser \& Miles (1979).

\section{Eastern Cape. Eocene}

1 slide: OS17926 (RVD939). Unpublished material from a single sample from Birbury Farm in the vicinity of East London, collected by RVD in 1967.

\section{Offshore Natal, borehole J(c)-1. Eocene-Oligocene}

18 slides: OS18354-18367, 18371-18375 (RVD1367-1380, 1386-1388). Borehole samples from the continental shelf off Natal collected by the Southern Oil Exploration Corporation (1971) and donated to RVD for analysis in 1973. The types and some of the figured specimens from this paper have been lost. An idiotype for Australileberis hieroglyphica sp. nov. Dingle, 1976 has since been created (OS17802, RVD815).

\section{Offshore Namaqualand, Orange River mouth. Miocene}

102 slides: OS17396-17469, 18601-18628 (RVD409-482, 1614-1641). Publication: Dingle et al. (2001). Also refer to the material of Mr N. D. Petersen (1983, unpublished University of Cape Town Honours Project, 'Vibracore Study of Sediments on the Inner and Middle Continental Shelf between the Orange River and Chamais Bay - South West Africa'). Comparative material, stratigraphical selections, faunal slides. Figured specimens and bulk of fauna is in the South African Museum, Cape Town. Residues from shallow-water vibrocores collected by De Beers Marine (Pty) Ltd during diamond exploration, 1974. Supplied to RVD by De Beers Marine (via Geological Survey of South Africa) and Dr I. K. McMillan.

Agulhas Bank and offshore SW Africa. Eocene, Miocene and uncertain 155 slides: OS17798-17901, 18629-18644, 18667-18701 (RVD811-914, 1642-1657, 1680-1714). Publications: Dingle (1993). Also refer to the material of J. Frewin (1987, unpublished University of Cape Town MSc, 'Palaeogene Ostracods from the South African Continental Shelf'). Comparative material and one idiotype (OS17802, RVD815 from TBD1706: Australileberis hieroglyphica Dingle, 1976, the holotype of which has been lost). Material collected by RVD and colleagues over the period 1968 to 1985 from R/V Thomas B Davie. Eocene: TBD 1105, 1125, 1276, 1288, 1303, 1706, 2833. Eocene?: TBD 559, 810, 6831. Miocene: TBD 2840, 3016, 3360, A4189, A4199. Uncertain age: TBD 3004.

Continental shelf offshore Namibia, R/V Professor Logachev, cruise 4, core 15. Miocene

21 slides: OS18645-18662, 18664-18666 (RVD1658-1675, 1677-1679). Undescribed collection from the outer continental shelf $(328 \mathrm{~m})$ offshore
Namibia $\left(24.71767^{\circ} \mathrm{S}, 13.7825^{\circ} \mathrm{E}\right.$, midway between Lüderitz and Walvis Bay). Collected by late Dr J. M. Bremner who donated the microfossils to RVD (1992).

\section{SOUTHERN AFRICA: QUATERNARY ONSHORE \& OFFSHORE}

SE Atlantic continental shelf. Holocene

338 slides: OS17947-18277, 18708-18713, 19319 (RVD960-1290, 1721-1726, 2332). Publications: Dingle (1992; 1993; 1994; 1995), Dingle \& Giraudeau (1993), Whatley \& Dingle (1989). Holotypes, paratypes, figured specimens, depth selections and faunal slides. Most types and figured specimens are in the South African Museum, Cape Town. Material collected by RVD and colleagues from the R/V Thomas B Davie over the period 1967 to 1987.

SE Atlantic - deep-water, Cape Basin. Quaternary/Holocene

76 slides: OS18278-18353 (RVD1291-1366). Publications: Dingle et al. (1990), Dingle \& Lord (1990). Topotypes, depth selection, comparative material. Holotypes, paratypes and figured specimens are in the South African Museum, Cape Town. Subset OS18278-18313 (RVD1291-1326) was collected by RVD and colleagues from R/V Thomas B Davie between 1971 and 1985. Depth range 900-2916 m. Subset OS18314-18353 (RVD1327-1366) was collected in 1988 from the Thomas B Davie (TBD cruise 512) and donated to RVD by Dr J. Rogers. Depth range 1060-4700 m.

Offshore Namibia, SE Atlantic, R/V Professor Logachev cruise 4, cores 13 (181 m), 14 (189 m), 15 (328 m), 16 (256 m). Late Pliocene-Late Pleistocene

556 slides: OS18663, 18702-18707, 18770-19318 (RVD1676, 1715-1720, 1783-2331). Publication: Dingle et al. (1996). Also refer to the data of P. J. Dillon \& J. M. Bremner (1992, unpublished document, University of Cape Town/Geological Survey, 'Report of Cruise 4, Leg 3 of the R.V. Professor Logachev: Sampling West Coast Pelletal Phosphorites. $5^{\text {th }}$ to $11^{\text {th }}$ May, 1992'). Depth selections, comparative material, faunal slides. Material collected by the late Dr J. M. Bremner, and donated to RVD as part of joint analytical programme on the Logachev cores.

Slides OS18702-18707 (RVD1715-1720) are from TBD 6931, the Walvis Bay box core, foraminifera from which are described by P. Gamson (1986. unpublished University College London MSc Report, Postgraduate Unit of Micropalaeontology, 'Palaeoenvironmental Interpretation of Holocene Benthic Foraminifera from off Walvis Bay').

Offshore SE Africa, deep-water, Natal Valley, R/V Professor Logachev cruise 4, cores 1 (3662 m), 4 (3841 m) and $6(4040 \mathrm{~m})$. Age uncertain, possibly Pleistocene

23 slides: OS18747-18769 (RVD1760-1782). Refer to data of R. S. McKeown (1993, unpublished Honours project, Geology Dept, University of Cape Town, 69pp., 'Benthic Foraminifera and Ostracoda from the Natal Valley, South-West Indian Ocean'). Figured specimens. Donated to RVD (project supervisor) by Mr R. S. McKeown in 1993.

Offshore Namibia, SE Atlantic, R/V Benguela cruise 192. Quaternary 33 slides: OS18714-18746 (RVD1727-1759). Undescribed material, but see data of J. M. Bremner, G. N. Baturin, P. Bova, D. Bühmann, W. Cupido, R. V. Dingle, J. Giraudeau, P. Monteiro \& Y. Nathan (1992, unpublished document, University of Cape Town/Geological Survey, 'Cruise Report B192, RV Benguela, 9th-20th March 1992'). Depth selections and comparative material. Vibrocores from mid-shelf, $\sim 40$ nautical miles SW of Walvis Bay. Collected by RVD as member of team led by the late Dr J. M. Bremner on R/V Benguela cruise 192 (1992).

\section{Knysna Estuary, southern Cape. Holocene}

24 slides: OS17902-17925 (RVD915-938). Publication: Benson \& Maddocks (1964). Topotypes and comparative material from some of Benson \& Maddocks' (1964) localities along the shores of Knysna Estuary. Most of these sites no longer exist because of commercial development. Collected by RVD in July 1968 .

Western Cape, marginal and non-marine. Quaternary \& Cenozoic? 43 slides: OS18406-18448 (RVD1419-1461). Publications: Dingle \& Honigstein (1994), Martens et al. (1996), Scholtz (1985). Comparative 
material and faunal slides. Marginal marine, hypo- and hyper-saline faunas from a variety of vleis, ponds and pits in the southwestern Cape coastal fringe (Cape Town to Olifants River). Main sites are: Verlorevlei, Rocher Pan, Soutkloof, Wadrif Salt Pan, Nuwedam, north shore of False Bay. Sites along the shore of Verlorevlei coincide with many of those described in Martens et al. (1996). All the types and figured specimens from Dingle \& Honigstein (1994) are in the South African Museum, Cape Town. Material collected by RVD in 1970, 1979 and 1993. One sample donated by Mr J. Pether (1985).

Slide OS18448 (RVD1461) is a freshwater assemblage from a diamond-pipe exploration borehole in a lacustrine sequence from Namaqualand, NW Cape. Precise locality unknown (Vaalputs, in the vicinity of Kliprand). Donated to RVD by Dr A. Scholtz c. 1987. Probably Cenozoic (see Scholtz, 1985).

\section{ANTARCTICA/NEW ZEALAND, UPPER CRETACEOUS}

197 slides: OS16596-16792 (RVD1-197). Publication: Dingle (2009). Holotypes, paratypes, figured specimens, other cited material, stratigraphical selections, comparative material and faunal slides.

\section{Antarctic Peninsula - James Ross \& Snow Hill Islands. Late Campanian}

45 slides: material from Snow Hill Island Formation, Santa Marta Formation and Hobbs Glacier Formation (Late Campanian). All material collected by RVD during December 1994 to January 1995, except sample DJ677.3 (collected by Dr D. Pirrie). Youngest Cretaceous ostracod faunas so far recorded from Antarctica.

\section{New Zealand. Cenomanian-Maastrichtian}

152 slides: Material from seven localities: Maastrichtian (Pukehou, MidWaipara Gorge, Woodside Creek, Rewa Stream, Mangatarata Road and Te Wainohu Point); Santonian (Te Wainohu Point); and Cenomanian (Rewa Stream and Coverham). All samples collected by RVD in 1981.

\section{ANTARCTICA, CENOZOIC}

\section{Victoria Land, Cape Roberts Drilling Project. Oligocene-} Quaternary

119 slides: OS17277-17395 (RVD290-408). Publications: Dingle (2000), Dingle \& Majoran (2001). Figured specimens, stratigraphical selections and faunal slides. This was an international, through-ice drilling project in the Ross Sea. RVD's contribution to the collaborative science was on three of the Cape Roberts Drilling Project sequences (CRP-1, CRP-2/2A and CRP-3). Material supplied via Dr P. Strong, New Zealand Geological Survey on behalf of the CRP team under Dr P. Barrett. Slides OS17277-17282 (RVD290-295) (CRP-3), mostly Oligocene. Slides OS17283-17327 (RVD296-340) (CRP-1), mostly Oligocene. Slides OS17328-17341 (RVD341-354) (CRP-1), Quaternary. Slides OS17342-17386 (RVD355399) (CRP-2/2A), Quaternary. Slides OS17387-17395 (RVD400-408) (CRP3), mostly Miocene. A feature, given the proximity to the South Pole, is the presence of the retrothermal genus Majungaella.

\section{SOUTHERN OCEAN, UPPER CRETACEOUS \& CENOZOIC} Falkland Plateau

62 slides. Publication: Dingle (1984). Topotypes, faunal slides, stratigraphical selections and comparative material from Deep Sea Drilling Project sites on the Falkland Plateau. Holotypes, paratypes and figured material are in the South African Museum, Cape Town.

DSDP Sites 327 and 330. Aptian-Albian

OS17226-17276, 18580-18586 (RVD239-289, 1593-1599).

DSDP Sites 327 and 330. Campanian-Maastrichtian

OS18576-18579 (RVD1589-1592). See also Majoran et al. 1998.

Ocean Drilling Program sites 329, 513, 689B, 699A, 1087B, C. Paleocene-Pleistocene

348 slides: OS17470-17797, 17927-17946 (RVD483-810, 940-959). All material obtained by RVD from ODP repository for research at Copenhagen University in 1998.
Southwestern Atlantic: West Georgia Basin, Argentine Basin, Falkland Plateau. Paleocene-Miocene

55 slides: OS17470-17524 (RVD483-537). Publication: Majoran \& Dingle (2001b). Figured specimens, stratigraphical selections, comparative material, faunal slides. West Georgia Basin (ODP 699A) - Paleocene, Oligocene, Eocene. Argentine Basin (ODP 513) - Oligocene. Falkland Plateau (DSDP 329) - Miocene.

Offshore Antarctica: Maud Rise - ODP 689B. Paleocene-Pliocene 145 slides: OS17525-17624, 17773-17797, 17927-17946 (RVD538-637, 786-810, 940-959). Publications: Majoran \& Dingle (2002). See also data of A. M. Sørensen (2002, unpublished Bachelor Project in Geology, Institute of Geology, University of Copenhagen, 'Deep-sea Cenozoic Ostracods from Maud Rise, Antarctica, and palaeo-oceanography of Southern Ocean'). Figured specimens, stratigraphical selections, comparative material, faunal slides.

\section{SE Atlantic: Cape Basin, Agulhas Ridge. Eocene-Pleistocene}

148 slides: OS17625-17772 (RVD638-785). Publication: Majoran \& Dingle (2001a). Stratigraphical selections, comparative material. Figured specimens are in the Geological Museum, University of Copenhagen (MGUH2566925689). Cape Basin (ODP 1087C): Eocene, Oligocene, Miocene, Pliocene, Pleistocene (OS17625-17703, RVD638-716). Agulhas Ridge (ODP 1088B/C): Oligocene, Miocene, Pliocene, Pleistocene (OS17704-17772, RVD717-785).

Prince Edward Islands archipelago. Holocene

69 slides: OS18450-18518 (RVD1463-1531). Publications: Dingle (2002; 2003). Depth selections, topotypes, faunal slides collected by epi-benthic sledge from South African Department of Transport vessel SA Agulhas. Donated by Dr J. Rogers to RVD c. 1990. Other elements of the benthic fauna have been studied at the Department of Zoology, University of Cape Town. HMS Challenger site \#145 (Brady, 1880) lies in the midst of the sampling grid.

Holotypes, paratypes and figured specimens are in the Natural History Museum Zoology Department (NHM 2002.996-1071). Other material is in the South African Museum, Cape Town (SAM MF1088-1157).

\section{SUNDRY MATERIAL}

USA (Hawaii \& Maryland). Neogene and Pleistocene

15 slides: OS18376-18390 (RVD1389-1403). Two small subsets donated to RVD by Dr J. Holden c. 1967.

Offshore Oahu, Hawaii. Neogene

OS18376-18380 (RVD1389-1393). Publication: Holden (1967). Comparative material, includes topotypes of Bairdia kauaiensis Holden, 1967. All specimens from sample T12 off Oahu Island (308 fathoms). Age uncertain, late Cenozoic, certainly post-Miocene.

Wailes Bluff, Maryland. Pleistocene

OS18381-18390 (RVD1394-1403). Publication: Cronin (1979).

Brazil, Sergipe Basin. Albian, Turonian

3 slides: OS18545-18547 (RVD1558-1560). Publications: Krömmelbein (1964; 1967). Topotypes of Aracajuia benderi Krömmelbein, 1967 and Sergipella transatlantica Krömmelbein, 1967 from Riachuelo Formation (Albian), locality Sergipe Krömmelbein 30, and Brachycythere (B.) sapucaiensis Krömmelbein, 1964 from Sapucari Formation (Turonian), locality Sergipe Krömmelbein 24. Turonian date for Sapucari Formation was revised to Lower Coniacian by Krömmelbein (1976). Donated to RVD by Dr K. Krömmelbein in early 1970s.

The original slides (from Krömmelbein to RVD) were labelled: 1. Brachycythere (B.) sapucariensis KRÖ, Sapucarí fm. L. Turonian, Sergipe, Brazil, loc. KRÖ. 24. 2. Sergipella transatlantica + Aracajuia benderi KRÖ, Riachuelo fm., Albian, Sergipe, Brazil, loc. KRÖ 30.

Tanzania, BP Lindi 1 \& 2 boreholes. Mid-Cretaceous 5 slides: OS19329-19324 (RVD2333-2337). Undescribed, but see Bate \& Bayliss (1969). Donated to RVD by BP (Sunbury) in early 1970s. 
Manuscript received 02 March 2012

Manuscript accepted 11 March 2012

Scientific editing by Elisabeth Brouwers

\section{REFERENCES}

Copies of many of these, together with unpublished data cited in the text, are lodged with the ostracod collection.

Bate, R.H. \& Bayliss, D.D. 1969. An outline account of the Cretaceous and Tertiary foraminifera and the Cretaceous ostracods of Tanzania. In Said, R., Ansary, S. El., Beckmann, J.P., Viotti, C., Ghorab, M.A. \& Kerdany, M.T. (Eds), Proceeding of the Third African Micropaleontological Colloquium, Cairo 1968. National Information and Documentation Centre, NIDOC, Cairo, U.A.R., 113-164.

Benson, R. \& Maddocks, R. 1964. Recent ostracodes of Knysna Estuary, Cape Province, Union of South Africa. Paleontological Contributions, University of Kansas, Arthropoda, Article 5, 1-39.

Brady, G.S. 1880. Report on the Ostracoda dredged by "HMS Challenger" during the years 1873-1876. Report of the Scientific Results of the Voyage of HMS Challenger during the years 1873-76 (Zoology), 1(3): 1-184.

Brenner, P. \& Oertli, H. 1976. Lower Cretaceous ostracodes (Valanginian to Hauterivian) from the Sundays River Formation, Algoa Basin, South Africa Bulletin de Centre Recherche Pau-SNPA, 10: 471-533.

Cronin, T. 1979. Late Pleistocene marginal marine ostracodes from the Southeastern Atlantic. Geographie Physique Quaternaire, 33: 121-173.

Dingle, R.V. 1969a. Marine Neocomian Ostracoda from South Africa. Transactions Royal Society South Africa, 38: 139-163.

Dingle, R.V. 1969b. Upper Senonian Ostracods from the coast of Pondoland. South Africa. Transactions Royal Society South Africa, 38: 347-385.

Dingle, R.V. 1971a. Some Cretaceous Ostracodal assemblages from the Agulhas Bank, South African continental margin. Transactions Royal Society South Africa, 39: $393-418$.

Dingle, R.V. 1971b. Cytherelloidea gardeni nom.nov. (Ostracoda). Transactions Royal Society South Africa, 39: 353.

Dingle, R.V. 1976. Palaeogene ostracods from the continental shelf off Natal, South Africa. Transactions Royal Society South Africa, 42: 35-79.

Dingle, R.V. 1980. Marine Santonian and Campanian ostracods from a borehole at Richards Bay, Zululand. Annals of the South African Museum, 82: 1-70.

Dingle, R.V. 1981. The Campanian and Mastrichtian Ostracoda of South-East Africa. Annals of the South African Museum, 85: 1-181.

Dingle, R.V. 1984. Mid-Cretaceous Ostracoda from southern Africa and the Falkland Plateau. Annals of the South African Museum, 93: 97-211.

Dingle, R.V. 1985. Turonian, Coniacian and Santonian Ostracoda from south-east Africa. Annals of the South African Museum, 96: 123-239.

Dingle, R.V. 1992. Quaternary ostracods from the continental margin off southwestern Africa. Part I. Dominant taxa. Annals of the South African Museum, 102: $1-89$.

Dingle, R.V. 1993. Quaternary ostracods from the continental margin off southwestern Africa. Part II. Minor taxa. Annals of the South African Museum, 103: $1-165$.

Dingle, R.V. 1994. Quaternary ostracods from the continental margin off south-western Africa. Part III. Oceanography and sedimentary environments. Annals of the South African Museum, 103: 383-441.

Dingle, R.V. 1995. Continental shelf upwelling and benthic Ostracoda in the Benguela System (southeastern Atlantic Ocean). Marine Geology, 122: 207-225.

Dingle, R.V. 1996. Cretaceous Ostracoda of the SE Atlantic \& SW Indian oceans: a stratigraphical review and atlas. Bulletin de Centre Recherche ExplorationProduction Elf Aquitaine, Memoir, 16: 1-17.

Dingle, R.V. 2000. Ostracoda from CRP-1 and CRP-2/2A,Victoria Land Basin, Antarctica. Terra Antartica, 7: 479-492.

Dingle, R.V. 2002. Insular endemism in Recent Southern Ocean benthic Ostracoda from Marion Island: palaeozoogeographical and evolutionary implications. Revista Española de Micropaleontología, 34: 215-233.

Dingle, R.V. 2003. Recent subantarctic benthic ostracod faunas from the Marion and Prince Edward islands archipelago, Southern Ocean. Revista Española de Micropaleontología, 35: 119-155.

Dingle, R.V. 2009. Implications for high latitude gondwanide palaeozoogeographical studies of some new Upper Cretaceous marine ostracod faunas from New Zealand and the Antarctic Peninsula. Revista Española de Micropaleontología, 41: $145-196$.

Dingle, R.V. \& Giraudeau, J. 1993. Benthic Ostracoda in the Benguela System (SE Atlantic): a multivariate analysis. Marine Micropaleontology, 22: 71-92.

Dingle, R.V. \& Honigstein, A. 1994. Ostracoda from Quaternary coastal environments in the south-western Cape. Annals of the South African Museum, 104: 63-114.
Dingle, R.V. \& Klinger, H.C. 1972. The stratigraphy and ostracod fauna of the Upper Jurassic sediments from Brenton, in the Knysna Outlier, Cape Province. Transactions Royal Society South Africa, 40: 279-298.

Dingle, R.V. \& Lord, A.R. 1990. Benthic ostracods and deep water-masses in the Atlantic Ocean. Palaeogeography, Palaeoclimatology, Palaeoecology, 80: 213-235.

Dingle, R.V. \& Majoran, S. 2001. Palaeo-climatic and -biogeographical implications of Oligocene Ostracoda from CRP-2/2A and CRP-3 drillholes, Victoria Land Basin. Terra Antartica, 8: 369-382.

Dingle, R.V., Lord, A.R. \& Boomer, I.D. 1990. Deep-water Quaternary Ostracoda from the continental margin off south-western Africa (SE Atlantic Ocean). Annals of the South African Museum, 99: 245-366.

Dingle, R.V., Bremner, J.M., Giraudeau, J. \& Buhmann, D. 1996. Modern and palaeo-oceanographic environments under Benguela upwelling cells off southern Namibia. Palaeogeography, Palaeoclimatology, Palaeoecology, 123: 85-105.

Dingle, R.V., McMillan, I.K., Majoran, S. \& Bisset, L. 2001. Palaeooceanographical implications of Early-Middle Miocene subtropical ostracod faunas from the continental shelf of the SE Atlantic Ocean. Palaeogeography, Palaeoclimatology, Palaeoecology, 173: 43-60.

Du Toit, S.R. \& Leith, M.J. 1974. The J(c)-1 borehole on the continental shelf near Stanger, Natal. Transactions of the Geological Society of South Africa, 77: $247-252$.

Holden, J. 1967. Late Cenozoic Ostracodes from the Drowned Terraces in the Hawaiian Islands. Pacific Science, 21: 1-50.

Kennedy, W.J. \& Klinger, H.C. 1975. Cretaceous faunas from Zululand and Natal, South Africa. Introduction, stratigraphy. Bulletin of the British Museum of Natural History (Geology), 25: 263-315.

Klinger, H.C. \& Kennedy, W.J. 1977. Upper Cretaceous ammonites from a borehole near Richards Bay, South Africa. Annals of the South African Museum, 72: 69-107.

Klinger, H.C., Kennedy, W.J. \& Dingle, R.V. 1972. A Jurassic Ammonite from South Africa. Neues Jahrbuch für Geologie und Paläontologie Monatshefte, 1972: 653-659.

Klinger, H.C., Kennedy, W.J. \& Siesser, W.G. 1976. Yabeiceras (Coniacian ammonite) from the Alphard Group off the southern Cape coast. Annals of the South African Museum, 69: 161-168.

Krömmelbein, K. 1964. Ostracoden aus der marinen "Küsten-Kreide Brasiliens, 1: Brachycythere (Brachycythere) sapucariensis n. $\mathrm{sp}$. aus dem Turonium. Senckenbergiana lethaea, 45: 489-495.

Krömmelbein, K. 1967. Ostracoden aus der marinen "Küsten-Kreide Brasiliens, 2: Sergipella transatlantica n.g., n.sp., und Aracjuia benderi n.g., n.sp., aus dem Ober-Aptium/Albium. Senckenbergiana lethaea, 48: 525-533.

Krömmelbein, K. 1976. Remarks on marine Cretaceous ostracodes of Gondwanic distribution. Proceedings of the 5th African Colloquium on Micropalaeontology, Addis Ababa, 1972. Revista Española de Micropaleontología, Publicación especial, Empresa Nacional Adaro, Enadimsa, 539-551.

Majoran, S. \& Dingle, R.V. 2001a. Palaeoceanographical changes recorded by Cenozoic deep-sea ostracod assemblages from the South Atlantic and Southern Ocean (ODP Sites 1087 and 1088). Lethaia, 34: 63-83.

Majoran, S. \& Dingle, R.V. 2001b. Cenozoic deep-sea ostracods from southwestern South Atlantic (DSDP/ODP sites 329, 513 and 699). Revista Española de Micropaleontología, 33: 205-215.

Majoran, S. \& Dingle, R.V. 2002. Cenozoic deep-sea ostracods from Maud Rise, Weddell Sea, Antarctica (OPD site 689): a palaeoceanographical perspective. Geobios, 35: 137-152.

Majoran, S., Kucera, M. \& Widmark, J.G.V. 1998. Maastrichtian deep-sea ostracods from DSDP/ODP Sites 327, 356, 525, 527, 528, 529 and 698 in the South Atlantic. Revista Española de Micropaleontología, 30: 59-73.

Martens, K., Davies, B.R., Baxter, A.J. \& Meadows, M.E. 1996. A contribution to the taxonomy and ecology of the Ostracoda (Crustacea) from Verlorenvlei (Western Cape, South Africa). South African Journal of Zoology, 31: 23-36.

McMillan, I.K. 2009. Early Campanian Foraminifera of the Igoda Formation and Needs Camp upper and lower quarries, Eastern Cape, South Africa, and comparison with Mzamba and the KwaZulu Basin. African Natural History, 5: 133-154.

Scholtz, A. 1985. The Palynology of the upper lacustrine sediments of the Arnot pipe, Banke, Namaqualand. Annals of the South African Museum, 95: 1-109.

Siesser, W.G. \& Miles, G.A. 1979. Calcareous nannofossils and planktic foraminifers in Tertiary limestone, Natal and eastern Cape, South Africa. Annals of the South African Museum, 79: 139-158.

Valicenti, V.H. \& Stephens, J.M. 1984. Ostracods from the Upper Valanginian and Upper Hautervian of the Sundays River Formation, Algoa Basin, South Africa. Revista Española de Micropaleontología, 16: 171-239.

Whatley, R.C. \& Dingle, R.V. 1989. First record of an extant, sighted, shallowwater species of the genus Poseidonamicus Benson (Ostracoda) from the continental margin of south-western Africa. Annals of the South African Museum, 98: $437-457$. 